\title{
Proses Penyusunan \\ Peraturan Rektor Universitas Gadjah Mada \\ Tentang Pola Klasifikasi Arsip di Lingkungan Universitas Gadjah Mada (studi Kasus di Arsip Universitas Gadjah Mada)
}

\section{$\begin{array}{lllllllll}\text { I } & \mathbf{N} & \mathbf{T} & \mathbf{I} & \mathbf{S} & \mathbf{A} & \mathbf{R} & \mathbf{I}\end{array}$}

Penelitian ini memberikan gambaran bagaimana proses pembuatan Peraturan Rektor Universitas Gadjah Mada (UGM) tentang Klasifikasi Arsip di Lingkungan UGM sejak penyusunan draf hingga diproses di Bagian Hukum dan Organisasi (Hukor) UGM. Metode penelitian yang digunakan dalam penelitian ini adalah action research dan penelitian deskriptif. Penelitian ini dilakukan sejak proses penyusunan draf klasifikasi arsip sampai dengan menjadi Peraturan Rektor UGM tentang Klasifikasi Arsip di Lingkungan UGM. Proses pembuatan peraturan rektor ini cukup rumit dengan waktu yang relatif panjang yaitu sejak tahun 2015 sampai dengan 2019. Saat proses pembuatan peraturan rektor ini masih berjalan, UGM mendapat undangan dari Kemenristekdikti untuk terlibat dalam pembahasan/penyusunan peraturan tentang klasifikasi arsip, jadwal retensi arsip dan sistem klasifikasi keamanan dan akses arsip. UGM turut berkontribusi dalam penyusunan Permenristekdikti Nomor 23 Tahun 2018 tentang Klasifikasi Arsip, Jadwal Retensi Arsip dan Sistem Klasifikasi Keamanan dan Akses Arsip Dinamis di Lingkungan Kementerian Riset, Teknologi, dan Pendidikan Tinggi.

\section{$\begin{array}{llllllll}A & B & S & T & R & A & C & T\end{array}$}

This study provides an overview of the process of making Rector's Regulation of Universitas Gadjah Mada (UGM) concerning Archive Classification in UGM since the preparation of the draft until it is processed in the Law and Organizational Division (Hukor) UGM. The research methods used in this study are action research and descriptive research. This research was carried out since the process of drafting the classification of the archive until it became the Rector's Regulation on the Classification of Archives in
PENULIS

Kurniatun

Arsip Universitas Gadjah Mada kurniatun@ugm.ac.id

KATA KUNCI

arsip, klasifikasi arsip, peraturan rektor 
UGM. The chancellor making process is quite complicated with a relatively long period of time, from 2015 to 2019. When the rector's decision-making process was still ongoing, UGM received an invitation from Kemenristekdikti to be involved in discussing regulations regarding about the classification of archives, archival retention schedules, and systems security classification and archive access. By bringing the draft, it can be said that UGM contributed to the drafting of Permenristekdikti Number 23 of 2018 concerning Archive Classification, Archival Retention Schedule, and Security Classification System and Dynamic Archive Access in the Ministry of Research, Technology and Higher Education.

\section{PENGANTAR}

Saat ini, setiap orang tidak bisa lepas dari benda yang bernama hand phone. Hand phone merupakan salah satu alat komunikasi untuk mendapatkan informasi dalam kehidupan sehari-hari. Begitu pula dengan suatu instansi atau organisasi, tidak bisa lepas dari informasi. Oleh karena itu, agar informasi dapat mendukung tercapainya tujuan organisasi, maka informasi harus dikelola dengan baik sesuai dengan perkembangan teknologi sehingga organisasi siap menghadapi perubahan zaman yang berkembang dengan sangat cepat. Arsip merupakan salah satu sumber informasi bagi organisasi. Untuk itu, arsip harus dikelola dengan baik sejak penciptaan sampai dengan penyusutan.

Demi kemudahan penyimpanan dan penemuan kembali arsip pada saat diperlukan, maka pengelolaan arsip sejak tahap penciptaan harus menggunakan sistem yang tepat, sesuai dengan karakterisitk organisasi. Salah satu instrumen yang dapat membantu kemudahan dalam penciptaan dan penyimpanan arsip adalah klasifikasi arsip. Klasifikasi arsip belum banyak digunakan di lingkungan Universitas Gadjah Mada (UGM), kalaupun ada yang menggunakan klasifikasi arsip masih sangat sedikit (baca: sebelum tahun $2015)$. Unit kerja yang telah menggunakan klasifikasi arsip rata-rata baru unit kerja yang menggunakan sistem subjek atau masalah pokok saja. Diantara unit kerja yang telah menggunakan klasifikasi arsip tersebut tidak ada yang seragam, misalnya: ada yang menggunakan klasifikasi buatan internal unit kerja, ada yang memakai Pola Klasifikasi dari Departemen Pendidikan Nasional Nomor 41268/A.A1/KP/2008, dan lain sebagainya.

Kebanyakan pemberkasan dan penyimpanan arsip dilakukan berdasarkan nomor urut agenda surat masuk dan surat keluar (kronologi waktu) sehingga surat masuk dan surat keluar 
disimpan terpisah. Sistem kronologi waktu cocok digunakan bagi organisasi yang relatif kecil dengan volume arsip yang tercipta tidak begitu banyak. Unit kerja di lingkungan UGM kurang cocok menggunakan sistem kronologi karena volume arsip yang tercipta sangat tinggi, sehingga penyimpanan arsip berdasarkan pada kronologi waktu tanpa menggunakan klasifikasi arsip akan menimbulkan kesulitan pada saat temu balik arsip dan penyusutan arsip. Hal itu disebabkan arsip tidak disimpan dalam satu kesatuan informasi tetapi hanya urut sesuai dengan kronologi waktu saja. Selain itu, ada juga pemberkasan yang dilakukan atas dasar inisiatif petugas kearsipan tanpa dengan menuliskan kode klasifikasi dan indeks arsip. Tentu saja hal ini akan menyebabkan kesulitan bagi petugas itu sendiri jika dia lupa dan menyulitkan akses arsip bagi petugas lain apabila petugas yang bersangkutan tidak berada di tempat.

Berdasarkan keadaan tersebut, maka Arsip UGM sebagai lembaga kearsipan perguruan tinggi (LKPT) yang berkewajiban melaksanakan penyelenggaraan kearsipan di lingkungan UGM, tergerak untuk segera membuat pembakuan klasifikasi arsip yang berlaku di seluruh UGM sebagai salah satu upaya untuk menertibkan kearsipan di lingkungan UGM.

Rumusan masalah yang disajikan dalam penelitian ini adalah bagaimana proses pembuatan draf klasifikasi arsip sampai menjadi Peraturan Rektor Universitas Gadjah Mada (UGM) tentang Klasifikasi Arsip di Lingkungan UGM, sejak proses pengumpulan data untuk penyusunan draf, penyempurnaan draf hingga draf final dikirim ke Bagian Hukum dan Organisasi (Hukor) UGM untuk proses penetapan sebagai peraturan rektor. Merujuk kepada rumusan masalah penelitian di atas, maka tulisan ini menyajikan informasi tentang: 1) Pembuatan draf awal klasifikasi arsip; 2) Proses pengumpulan data lapangan dalam rangka perbaikan draf awal klasifikasi arsip di lingkungan UGM; 3) Proses memperbaiki draf klasifikasi; dan 4) Proses menjadi Peraturan Rektor UGM tentang Klasifikasi Arsip di Lingkungan UGM.

\section{Metode Penelitian}

Metode yang digunakan dalam penelitian ini adalah action research dan penelitian deskriptif. Menurut Sujarwadi (2014:10) yang dimaksud dengan penelitian tindakan adalah suatu penelitian yang ditujukan untuk menemukan metode yang paling efektif dalam kegiatan sehari-hari dalam suatu instansi, organisasi maupun perusahaan. Melalui metode ini peneliti berharap dapat menyeimbangkan antara teori dan praktik. Pelaksanakan metode ini dilakukan dengan:

1. Identifikasi permasalahan tentang klasifikasi arsip unit kerja; 
2. Perencanaan survei klasifikasi arsip;

3. Pelaksanaan survei klasifikasi arsip di unit kerja di lingkungan UGM;

4. Perbaikan draf klasifikasi arsip dengan memasukkan data tambahan yang diperoleh dari unit kerja; dan

5. Evaluasi dengan melihat dampak yang ditimbulkan dari kegiatan survei antara draf awal klasifikasi arsip yang dibuat oleh Tim Penyusun Klasifikasi Arsip dan pasca kegiatan survei klasifikasi arsip dari unit kerja di lingkungan UGM.

Metode penelitian yang kedua adalah dengan menggunakan metode penelitian deskriptif. Adapun yang dimaksud dengan metode penelitian deskriptif adalah metode penelitian yang berusaha mengungkap fakta suatu kejadian, objek, aktivitas, proses dan manusia secara "apa adanya" pada waktu sekarang atau jangka waktu yang masih memungkinkan dalam ingatan responden (Prastowo, 2016:203). Penelitian ini dilakukan untuk memperoleh informasi deskriptif tentang fenomena sosial yang diteliti. Melalui data deskriptif, penulis berharap dapat mengidentifikasi mengapa, apa dan bagaimana klasifikasi arsip yang digunakan di lingkungan UGM atau bahkan mengapa, apa dan bagaimana unit kerja tidak menggunakan klasifikasi arsip. Tujuan penggunaan metode penelitian deskriptif dalam penelitian ini dimaksudkan agar penulis dapat mendeskripsikan, menjelaskan, dan memvalidasi temuan penelitian yang sudah dilakukan. Melalui metode penelitian deskriptif ini, penulis berharap dapat:

1. Menganalisis penggunaan klasifikasi arsip di unit kerja di lingkungan UGM;

2. Melakukan pengamatan tentang penggunaan klasifikasi arsip di unit kerja di lingkungan UGM secara apa adanya; dan

3. Dimungkinkan untuk dilakukan kombinasi penelitian kualitatif dan kuantitatif.

\section{Kerangka Pemikiran}

Dua hal yang dibahas pada kerangka pemikiran dalam artikel ini adalah tentang arsip dan klasifikasi arsip. Ricks, Swafford \& Gow (1992:3) dalam Sumartini menjelaskan bahwa: $A$ record is recorded information, regardless of medium or characteristic, made or received by an organization that is useful on the operation. Record include all books, papers, photographs, maps, or other documentary materials, regardless of physical or characteristic, made or received for legal and business.

Arsip adalah informasi yang direkam, terlepas dari media atau karakteristik, yang dibuat atau diterima oleh organisasi yang berguna bagi operasional organisasi, yang mencakup semua media baik buku, kertas, foto, peta, atau bahan dokumenter lainnya, terlepas dari fisik atau karakteristiknya, dibuat atau diterima untuk keperluan hukum dan bisnis. 
Pengertian tersebut hampir sama dengan pengertian arsip menurut UndangUndang (UU) No. 43 Tahun 2009 tentang Kearsipan. Pasal 1 (2) UU No. 43 Tahun 2009 menyebutkan:

Arsip adalah rekaman kegiatan atau peristiwa dalam berbagai bentuk dan media sesuai dengan perkembangan teknologi informasi dan komunikasi yang dibuat dan diterima oleh lembaga negara, pemerintahan daerah, lembaga pendidikan, perusahaan, organisasi politik, organisasi $\mathrm{k}$ e m a s y a a k a t a n, d a n perseorangan dalam pelaksanaan kehidupan bermasyarakat, berbangsa, dan bernegara.

Berdasarkan dua pengertian tentang arsip tersebut maka dapat disimpulkan bahwa arsip adalah rekaman informasi dalam segala bentuk dan media yang dibuat dan diterima oleh suatu organisasi.

Setelah diketahui pengertian tentang arsip, selanjutnya adalah pembahasan tentang klasifikasi arsip. Hadiwardoyo (2002:63) menyatakan bahwa "klasifikasi arsip merupakan identifikasi sistematis dan pengaturan terhadap informasi mengenai kegiatan kerja ke dalam katagori-katagori menurut kesepakatan, metoda, dan ketentuan prosedural yang terstruktur secara logis, yang terwujud dalam sistem klasifikasi."

Selain itu, Hadiwardoyo (2002:63) juga memberikan penjelasan tentang model klasifikasi. Model klasifikasi dikembangkan dari kerangka teoritis bahwa arsip yang tercipta pada sesuatu instansi atau organisasi merupakan endapan informasi yang terekam mengenai segala hal yang menjadi kompetensinya. Selanjutnya, Hadiwardoyo (2002:65) memberikan penjelasan tentang kode klasifikasi arsip. Adapun yang dimaksud kode klasifikasi adalah:

Seperangkat aturan untuk menandai data, karakteristik dan pesan yang digunakan dalam sistem klasifikasi pengelolaan berkas. Kode disusun secara hirarkis sehingga tampak hubungan keterkaitan nyata antara tanda pada tingkat seri arsip/ butir klasifikasi, berkas, dan folder/ naskah. Dengan melihat kode akan dapat diperoleh kepastian bahwa sesuatu naskah terdapat dalam folder/ berkas yang relevan.

Berdasarkan Permenristekdikti Nomor 23 Tahun 2018 tentang Klasifikasi Arsip, Jadwal Retensi Arsip, dan Sistem Klasifikasi Keamanan dan Akses Arsip Dinamis (KA, JRA, SKKAA) di Lingkungan Kemenristekdikti dan Peraturan Kepala ANRI Nomor 19 Tahun 2012 tentang Pedoman Penyusunan Klasifikasi Arsip, skema/ pola klasifikasi adalah pola pengaturan arsip secara berjenjang dari hasil pelaksanaan fungsi dan tugas instansi menjadi beberapa kategori unit informasi kearsipan. Tujuan diterapkannya pola klasifikasi arsip adalah untuk menjamin pengelolaan arsip secara efektif dan efisien. Hal ini dimaksudkan agar arsip yang diciptakan 
atau diterima dalam rangka pelaksanaan fungsi dan kegiatan organisasi dapat diatur dengan mudah sehingga apabila diperlukan dengan sewaktu-waktu dapat ditemukan kembali dengan tepat dan cepat. Demikian pula pada saat penyusutan juga akan lebih mudah karena arsip sudah memberkas dalam satu kesatuan.

Sambas Ali dan Hendri Winata (Ratu Fauziah, 2018:31) menyatakan bahwa kegunaan skema klasifikasi arsip, yaitu:

1. Pedoman baku untuk penataan arsip yang didasarkan pada sistem pemberkasan subjek;

2. Keutuhan informasi, arsip dari aktivitas atau masalah yang sama akan mengelompok dalam satu berkas;

3. Mengatur penyimpanan arsip secara logis dan sistematis;

4. Mendukung secara langsung penyusutan arsip; dan

5. Sebagai sarana pengendalian dan membantu mempercepat penemuan kembali arsip.

Dari uraian di atas dapat disimpulkan bahwa pada dasarnya klasifikasi arsip berfungsi untuk:

1. Mempermudah pada saat penyimpanan arsip;

2. Mempermudah pada saat penemuan kembali arsip; dan

3. Mempermudah pada saat proses penyusutan arsip.

\section{PEMBAHASAN}

\section{Perencanaan}

Kegiatan penyusunan klasifikasi arsip diawali dengan kegiatan perencanaan yang meliputi perencanaan dalam bidang anggaran dan teknis. Terkait dengan anggaran, kegiatan penyusunan klasifikasi arsip ini dimasukkan dalam program kerja Arsip UGM Tahun 2015 dan Rencana Kegiatan dan Anggaran Tahunan (RKAT) Arsip UGM tahun 2016. Tahun 2015 belum membutuhkan anggaran karena baru dalam tahap penyusunan draf. Kegiatan penyusunan klasifikasi arsip perlu masuk RKAT 2016 karena dalam pelaksanaannya akan membutuhkan biaya yang cukup banyak, yaitu: biaya untuk penggandaan draf klasifikasi arsip yang akan dikirimkan ke unit kerja, biaya Focus Group Discussion ( F G D ) un tuk membahas penyempurnaan draf, honorarium narasumber, dan lain-lain.

Setelah mendapatkan kepastian bahwa kegiatan penyusunan klasifikasi arsip ini masuk dalam RKAT Arsip UGM tahun 2016, maka kegiatan ini pun dapat mulai dilaksanakan. Langkah pertama yang dilakukan adalah dengan penyusunan Tim Penyusun Klasifikasi Arsip. Anggota tim terdiri dari para arsiparis yang ditunjuk oleh Kepala Arsip UGM dan ditetapkan dengan surat tugas. 


\section{Penyusunan Draf}

Penyusunan draf klasifikasi arsip dilakukan oleh Tim Penyusun Klasifikasi Arsip. Tim ini terdiri dari beberapa arsiparis Arsip UGM yang ditunjuk oleh Kepala Arsip UGM pada tahun 2015. Adapun dasar hukum yang digunakan oleh Tim Penyusun Klasifikasi Arsip dalam rangka penyusunan draf klasifikasi adalah

a. Undang-Undang Nomor 43 Tahun 2009 tentang Kearsipan (Lembaran Negara Republik Indonesia Tahun 2009 Nomor 152, Tambahan Lembaran Negara Republik Indonesia Tahun 2009 Nomor 5071);

b. Undang-Undang Nomor 12 Tahun 2012 tentang Pendidikan Tinggi (Lembaran Negara Republik Indonesia Tahun 2012 Nomor 158, Tambahan Lembaran Negara Nomor 5336);

c. Peraturan Pemerintah Nomor 28 Tahun 2012 tentang Pelaksanaan Undang- Undang Nomor 43 Tahun 2009 tentang Kearsipan (Lembaran Negara Republik Indonesia Tahun 2012 Nomor 53, Tambahan Lembaran Negara Republik Indonesia Nomor 5286);

d. Peraturan Pemerintah Nomor 67 Tahun 2013 tentang Statuta Universitas Gadjah Mada (Lembaran Negara Republik Indonesia Tahun 2013 Nomor 165 Tambahan Lembaran Negara
Republik Indonesia Nomor 5454);

e. Peraturan Pemerintah Nomor 4 Tah un 2014 te n t a n g Penyelenggaraan Pendidikan Tinggi dan Pengelolaan Perguruan Tinggi (Lembaran Negara Republik Indonesia Tahun 2014 Nomor 16, Tambahan Lembaran Negara Republik Indonesia Nomor 5500);

f. Peraturan Pemerintah Nomor 26 Tahun 2015 tentang Bentuk dan Mekanisme Pendanaan Perguruan Tinggi Negeri Badan Hukum (Lembaran Negara Republik Indonesia Tahun 2015 Nomor 110, Tambahan Lembaran Negara Republik Indonesia Nomor 5699);

g. Peraturan Menteri Pendidikan dan Kebudayaan Nomor 60 Tahun 2012 tentang Pengelolaan Arsip dan Dokumentasi serta Informasi Publik di Lingkungan Kementerian Pendidikan dan Kebudayaan;

h. Peraturan Menteri Pendidikan dan Kebudayaan Nomor 06 Tahun 2013 tentang Tata Naskah Dinas di Lingkungan Kementerian Pendidikan dan Kebudayaan;

i. Peraturan Majelis Wali Amanat Universitas Gadjah Mada Nomor 4/SK/MWA/2014 tentang Organisasi dan Tata Kelola (Governance) Universitas Gadjah Mada; dan

j. Peraturan Majelis Wali Amanat 
Universitas Gadjah Mada Nomor

12/SK/MWA/2015 tentang

Penetapan Rektor Universitas

Gadjah Mada Pengganti Antar

Waktu Periode 2012-2017.

Langkah pertama yang dilakukan dalam pembuatan draf awal klasifikasi arsip adalah dengan melakukan pencematan terhadap klasifikasi arsip yang digunakan oleh Arsip UGM. Draf awal klasifikasi arsip disusun pada tahun 2015 dengan mengadopsi Keputusan Sekretaris Jenderal
Departemen Pendidikan Nasional (SK Sekjen Depdiknas) Nomor 41268/A.A1/KP/2008 tentang Pola Klasifikasi Kearsipan di Lingkungan Depdiknas. Klasifikasi arsip yang digunakan di Arsip UGM berdasarkan peraturan tersebut, namun sudah diberi tambahan-tambahan sesuai dengan kondisi yang ada di Arsip UGM pada khususnya dan UGM pada umumnya. Adapun main subjek dalam draf klasifikasi arsip adalah

Tabel 1

Masalah Pokok (Subjek) Klasifikasi Arsip

\begin{tabular}{|c|c|c|}
\hline \multicolumn{3}{|r|}{ MASALAH FASILITATIF } \\
\hline No. & Kode & Masalah \\
\hline 1. & KU & Keuangan \\
\hline 2. & KP & Kepegawaian \\
\hline 3. & HK & Hukum \\
\hline 4. & OT & Organisasi dan Tata Kerja \\
\hline 5. & $\mathrm{HM}$ & Kehumasan \\
\hline 6. & PR & Perencanaan \\
\hline 7. & LK & Perlengkapan \\
\hline 8. & TU & Ketatausahaan \\
\hline 9. & TI & Teknologi Informasi dan Komunikasi \\
\hline 10. & $\mathrm{DL}$ & Pendidikan dan Pelatihan \\
\hline 11. & PG & Penelitian dan Pengembangan \\
\hline 12. & WS & Pengawasan \\
\hline \multicolumn{3}{|r|}{ MASALAH SUBSTANTIF } \\
\hline No. & Kode & Masalah \\
\hline 1. & DM & Pendidikan Dasar dan Menengah \\
\hline 2. & DT & Pendidikan Tinggi \\
\hline 3. & $\mathrm{NF}$ & Pendidikan Nonformal dan Informal \\
\hline 4. & $\mathrm{~PB}$ & Pembinaan dan Pengembangan Bahasa \\
\hline 5. & KG & Kegrafikan \\
\hline 6. & $\mathrm{BK}$ & Pembukuan \\
\hline 7. & KJ & Pengembangan Kualitas Jasmani \\
\hline 8. & $\mathrm{TP}$ & Teknologi Pendidikan \\
\hline 9. & $\mathrm{PD}$ & Pendidikan dan Tenaga Kependidikan \\
\hline 10. & PP & Perkuliahan/ Penyelenggaraan Pendidikan \\
\hline 11. & $\mathrm{KS}$ & Koordinasi Perguruan Tinggi \\
\hline
\end{tabular}

Sumber: SK Sekjen Depdiknas) Nomor 41268/A.A1/KP/2008 tentang Pola Klasifikasi Kearsipan di Lingkungan Depdiknas. 
Selain mengadopsi dari SK Sekjen Depdiknas Nomor 41268/A.A1/KP/2008 tentang Pola Klasifikasi Kearsipan di Lingkungan Depdiknas, sumber lain yang menjadi rujukan menyusun draf klasifikasi arsip adalah Peraturan Rektor UGM Nomor $408 / \mathrm{P} / \mathrm{SK} / \mathrm{HT} / 2009$ tentang Jadwal Retensi Arsip dan Pedoman Penyusutan Arsip di
Lingkungan Universitas Gadjah Mada. Dari peraturan rektor tersebut diperoleh item-item arsip yang tercipta pada berbagai bidang/ masalah di lingkungan UGM sehingga dapat digunakan/ ditambahkan dalam penyusunan draf klasifikasi arsip. Tabel 2 menunjukkan contoh klasifikasi arsip pada main subjek "Ketatausahaan":

Tabel 2

Klasifikasi Arsip "Ketatausahaan” Berdasarkan SK Sekjen Depdiknas No. 41268/A.A1/KP/2008 tentang Pola Klasifikasi Kearsipan di Lingkungan Depdiknas

\begin{tabular}{|c|c|}
\hline TU & KETATAUSAHAAN \\
\hline & TU.00 Persuratan \\
\hline & TU.01 Penggandaan \\
\hline & TU.02 Kearsipan \\
\hline & TU.03 Kerumahtanggaan \\
\hline & 00 Kendaraan dinas \\
\hline & 01 Konsumsi dan akomodasi \\
\hline & 02 Perawatan \\
\hline & 03 Perjalanan dinas \\
\hline & 04 Pengurusan VISA/ Paspor \\
\hline & 05 Mess, Rumah Jabatan, rumah dinas, wisma, villa, hotel, penginapan \\
\hline & 06 Telekomunikasi \\
\hline & 07 Kebersihan dan taman \\
\hline & TU.04 Keamanan dan Ketertiban \\
\hline & 00 Personil \\
\hline & 01 Dokumen \\
\hline & 02 Material/ fisik \\
\hline
\end{tabular}

Sumber: SK Sekjen Depdiknas Nomor 41268/A.A1/KP/2008 tentang Pola Klasifikasi Kearsipan di Lingkungan Depdiknas. 
Tabel 2 menunjukkan bahwa klasifikasi arsip untuk main subjek (masalah pokok) "Ketatausahaan" terdiri atas lima subsubjek (submasalah) yaitu persuratan; penggandaan ; kearsipan; kerumahtanggaan; dan keamanan dan ketertiban, sedangkan yang sampai dengan s ub s ubsubjek ad a lah "kerumahtanggaan" dan "keamanan dan ketertiban". Subsubjek "kerumahtanggaan" mempunyai 10 (sepuluh) sub subsubjek, yaitu: kendaraan dinas; konsumsi dan akomodasi; perawatan, perjalanan dinas; pengurusan VISA/ paspor; mess, rumah jabatan, rumah dinas, wisma, villa, hotel, penginapan; telekomunikasi; kebersihan dan taman; listrik, air, AC; dan sepeda kampus, sedangkan subsubjek "Keamanan dan Ketertiban" mempunyai tiga sub subsubjek, yaitu: personil; dokumen; dan material/ fisik.

Kenyataan di lapangan ternyata klasifikasi arsip untuk main subjek "Ketatausahaan" belum cukup mengakomodir dari beragamnya arsip yang tercipta di Arsip UGM. Penambahanpenambahan yang telah dilakukan untuk klasifikasi arsip main subjek "Ketatausahaan" seperti tercantum pada tabel 3 berikut ini: 
Tabel 3

Klasifikasi Arsip "Ketatausahaan” yang Digunakan di Arsip UGM

\section{TU KETATAUSAHAAN}

TU.00 Persuratan

00 Surat Tugas/ surat keterangan

01 Ucapan terima kasih, pengantar pengiriman barang

02 Ucapan selamat

03 Pengumuman/ pemberitahuan/ permohonan

04 Undangan

TU.01 Penggandaan

TU.02 Kearsipan

$00 \quad$ Arsip Dinamis

01 Undangan (terkait kearsipan), notulen

02 Data pengelola/ arsiparis

03 Pengelolaan arsip

04 Forum kearsipan

$05 \quad$ Akuisisi

06 Keanggotaan ICA

07 Pelayanan Arsip

08 Penyusutan Arsip

TU.03 Kerumahtanggaan

$00 \quad$ Kendaraan dinas

01 Konsumsi dan akomodasi

02 Perawatan

03 Perjalanan dinas

04 Pengurusan VISA/ Paspor

05 Mess, rumah jabatan, rumah dinas, wisma, villa, hotel, penginapan

06 Telekomunikasi

07 Kebersihan dan taman

08 Listrik, air, AC

09 Sepeda kampus

TU.04 Keamanan dan Ketertiban

$00 \quad$ Personil

01 Dokumen

02 Material/fisik

03 Penutupan jalan/parkir/ penertiban lingkungan

Sumber: Arsip UGM, 2015 
Berdasarkan tabel 3 dapat diketahui bahwa pada subsubjek "Persuratan" dilakukan penambahan 5 (lima) sub subsubjek yaitu surat tugas/ surat keterangan; ucapan terima kasih, pengantar pengiriman barang; ucapan s e la mat; pengum u man/ pemberitahuan/ permohonan; dan undangan. Begitu juga untuk subsubjek "Kearsipan" juga terjadi penambahan 9 (sembilan) sub subsubjek. Begitu pula dengan 'Kerumahtanggaan" terjadi penambahan 2 (dua) sub subsubjek sehingga yang awalnya 8 (delapan) menjadi 10 (sepuluh), yaitu dengan penambahan listrik, air, AC dan sepeda kampus. Subsubjek "Keamanan dan Ketertiban" juga mendapat tambahan satu sub subsubjek yaitu penutupan jalan/ parkir/ penertiban lingkungan. Demikian contoh penambahan yang dilakukan dalam pola klasifikasi arsip sehingga terwujud draf awal klasifikasi. Draf awal klasifikasi arsip ini selesai disusun pada akhir tahun 2015 sehingga awal tahun 2016 survei klasifikasi arsip siap dilaksanakan.

\section{Survei Lapangan}

Setelah draf awal klasifikasi arsip selesai dibuat oleh Tim Penyusun Klasifikasi Arsip dan diadakan pencermatan bersama oleh seluruh arsiparis di Arsip UGM pada akhir tahun 2015, draf awal klasifikasi arsip kemudian digandakan sebanyak jumlah unit kerja yang menjadi target survei klasifikasi arsip. Awal tahun 2016 dilakukan survei klasifikasi arsip di lingkungan UGM di beberapa fakultas, seluruh direktorat, beberapa pusat studi, bidang usaha, pamong universitas dan unit kerja lainnya. Fakultas yang disurvei terdiri dari beberapa fakultas eksakta dan beberapa noneksakta. Metode yang digunakan dalam survei ini adalah draf dikirim terlebih dahulu ke unit kerja (dalam bentuk hardcopy dan softcopy) agar bisa dicermati dan dipelajari terlebih dahulu sehingga saat Tim Survei dari Arsip UGM dating, unit kerja sudah siap dengan data-data tambahan yang berkaitan dengan arsip yang tercipta di unit kerja masingmasing sesuai dengan tugas dan fungsinya. Dengan kata lain, unit kerja sudah siap saat disurvei dan dapat memberikan masukan-masukan untuk drafklasifikasi arsip.

Survei dilakukan oleh para arsiparis dengan didampingi seorang kepala bidang. Tim survei bertanggung jawab untuk mencatat atau merekam data-data yang diberikan oleh unit kerja dalam rangka perbaikan draf klasifikasi arsip. Tabel 4 menyajikan informasi tentang jadwal survei klasifikasi arsip pada tahun 2016. 
Tabel 4

Jadwal Survei Klasifikasi Arsip di Lingkungan UGM

\begin{tabular}{|c|c|c|c|c|c|}
\hline No & Hari/ Tanggal & Unit Kerja & Waktu & Kelompok & Pendamping \\
\hline 1 & $\begin{array}{l}\text { Senin, } 29 \\
\text { Februari } 2016\end{array}$ & $\begin{array}{l}\text { Fakultas } \\
\text { ISIPOL }\end{array}$ & 09.00-11.00 & Kelompok I & $\begin{array}{l}\text { Kabid. } \\
\text { Layanan }\end{array}$ \\
\hline 2 & $\begin{array}{l}\text { Senin, } 29 \\
\text { Februari } 2016 \\
\end{array}$ & \begin{tabular}{|l|} 
Fakultas \\
Kedokteran \\
\end{tabular} & $09.00-11.00$ & Kelompok II & $\begin{array}{l}\text { Kabid. } \\
\text { Database }\end{array}$ \\
\hline 3 & $\begin{array}{l}\text { Senin, } 29 \\
\text { Februari } 2016\end{array}$ & \begin{tabular}{|l} 
Fakultas \\
Peternakan
\end{tabular} & $13.00-15.00$ & Kelompok III & $\begin{array}{l}\text { Kabid. } \\
\text { Layanan }\end{array}$ \\
\hline 4 & \begin{tabular}{|l} 
Selasa, 1 \\
Maret 2016 \\
\end{tabular} & Fakultas Teknik & $09.00-11.00$ & Kelompok III & $\begin{array}{l}\text { Kabid. } \\
\text { Database }\end{array}$ \\
\hline 5 & \begin{tabular}{|l} 
Selasa, 1 \\
Maret 2016
\end{tabular} & Sekolah Vokasi & $09.00-11.00$ & Kelompok II & $\begin{array}{l}\text { Kabid. } \\
\text { Layanan }\end{array}$ \\
\hline 6 & $\begin{array}{l}\text { Selasa, 1 } \\
\text { Maret 2016 } \\
\end{array}$ & $\begin{array}{l}\text { Sekolah } \\
\text { Pascasarjana } \\
\end{array}$ & $13.00-15.00$ & Kelompok I & $\begin{array}{l}\text { Kabid. } \\
\text { Database }\end{array}$ \\
\hline 7 & $\begin{array}{l}\text { Rabu, } 2 \text { Maret } \\
2016\end{array}$ & $\begin{array}{l}\text { Pusat Studi } \\
\text { Kependudukan } \\
\text { dan Kebijakan } \\
\end{array}$ & $09.00-11.00$ & Kelompok III & $\begin{array}{l}\text { Kabid. } \\
\text { Layanan }\end{array}$ \\
\hline 8 & $\begin{array}{l}\text { Rabu, } 2 \text { Maret } \\
2016\end{array}$ & $\begin{array}{l}\text { Pusat Studi } \\
\text { Pancasila }\end{array}$ & $09.00-11.00$ & Kelompok I & $\begin{array}{l}\text { Kabid. } \\
\text { Database }\end{array}$ \\
\hline 9 & $\begin{array}{l}\text { Rabu, } 2 \text { Maret } \\
2016\end{array}$ & $\begin{array}{l}\text { Pusat Studi } \\
\text { Pedesaan dan } \\
\text { Kawasan }\end{array}$ & $13.00-15.00$ & Kelompok II & $\begin{array}{l}\text { Kabid. } \\
\text { Layanan }\end{array}$ \\
\hline 10 & \begin{tabular}{|l|} 
Kamis, 3 Maret \\
2016
\end{tabular} & $\begin{array}{l}\text { Majelis Wali } \\
\text { Amanah }\end{array}$ & $09.00-11.00$ & Kelompok III & $\begin{array}{l}\text { Kabid. } \\
\text { Database }\end{array}$ \\
\hline 11 & \begin{tabular}{|l|} 
Kamis, 3 Maret \\
2016
\end{tabular} & $\begin{array}{l}\text { Majelis Guru } \\
\text { Besar }\end{array}$ & $09.00-11.00$ & Kelompok II & $\begin{array}{l}\text { Kabid. } \\
\text { Layanan }\end{array}$ \\
\hline 12 & \begin{tabular}{|l|} 
Kamis, 3 Maret \\
2016
\end{tabular} & Senat Akademik & $13.00-15.00$ & Kelompok I & $\begin{array}{l}\text { Kabid. } \\
\text { Database }\end{array}$ \\
\hline 13 & $\begin{array}{l}\text { Senin, } 7 \text { Maret } \\
2016\end{array}$ & $\begin{array}{l}\text { Sekretariat } \\
\text { Universitas } \\
\end{array}$ & 09.00-11.00 & Kelompok III & $\begin{array}{l}\text { Kabid. } \\
\text { Layanan }\end{array}$ \\
\hline 14 & $\begin{array}{l}\text { Senin, } 7 \text { Maret } \\
2016\end{array}$ & $\begin{array}{l}\text { Direktorat } \\
\text { Pendidikan dan } \\
\text { Pengajaran }\end{array}$ & 09.00-11.00 & Kelompok I & $\begin{array}{l}\text { Kabid. } \\
\text { Database }\end{array}$ \\
\hline 15 & $\begin{array}{l}\text { Senin, } 7 \text { Maret } \\
2016\end{array}$ & $\begin{array}{l}\text { Direktorat } \\
\text { Penelitian }\end{array}$ & $13.00-15.00$ & Kelompok II & $\begin{array}{l}\text { Kabid. } \\
\text { Layanan }\end{array}$ \\
\hline
\end{tabular}




\begin{tabular}{|c|c|c|c|c|c|}
\hline 16 & $\begin{array}{l}\text { Selasa, } 8 \text { Maret } \\
2016\end{array}$ & \begin{tabular}{|l} 
Direktorat \\
Pengabdian \\
kepada \\
Masyarakat \\
\end{tabular} & $09.00-11.00$ & Kelompok I & $\begin{array}{l}\text { Kabid. } \\
\text { Database }\end{array}$ \\
\hline 17 & \begin{tabular}{|l|} 
Selasa, 8 Maret \\
2016
\end{tabular} & \begin{tabular}{|l|} 
Direktorat \\
Kemahasiswaan \\
\end{tabular} & $09.00-11.00$ & Kelompok II & $\begin{array}{l}\text { Kabid. } \\
\text { Layanan }\end{array}$ \\
\hline 18 & \begin{tabular}{|l|} 
Selasa, 8 Maret \\
2016
\end{tabular} & \begin{tabular}{|l} 
Direktorat \\
Perencanaan
\end{tabular} & $13.00-15.00$ & Kelompok III & $\begin{array}{l}\text { Kabid. } \\
\text { Database }\end{array}$ \\
\hline 19 & $\begin{array}{l}\text { Kamis, } 10 \\
\text { Maret } 2016\end{array}$ & \begin{tabular}{|l|} 
Direktorat \\
Keuangan \\
\end{tabular} & $09.00-11.00$ & Kelompok III & $\begin{array}{l}\text { Kabid. } \\
\text { Layanan }\end{array}$ \\
\hline 20 & $\begin{array}{l}\text { Kamis, } 10 \\
\text { Maret } 2016\end{array}$ & $\begin{array}{l}\text { Direktorat } \\
\text { Sumber Daya } \\
\text { Manusia }\end{array}$ & $09.00-11.00$ & Kelompok II & $\begin{array}{l}\text { Kabid. } \\
\text { Database }\end{array}$ \\
\hline 21 & \begin{tabular}{|l|} 
Kamis, 10 \\
Maret 2016 \\
\end{tabular} & Direktorat Aset & $13.00-15.00$ & Kelompok I & $\begin{array}{l}\text { Kabid. } \\
\text { Layanan }\end{array}$ \\
\hline 22 & $\begin{array}{l}\text { Jumat, } 11 \\
\text { Maret } 2016\end{array}$ & $\begin{array}{l}\text { Direktorat } \\
\text { Kemitraan dan } \\
\text { Alumni } \\
\end{array}$ & $09.00-11.00$ & Kelompok III & $\begin{array}{l}\text { Kabid. } \\
\text { Database }\end{array}$ \\
\hline 23 & $\begin{array}{l}\text { Jumat, } 11 \\
\text { Maret } 2016\end{array}$ & $\begin{array}{l}\text { Direktorat } \\
\text { Usaha dan } \\
\text { Inkubasi } \\
\end{array}$ & $09.00-11.00$ & Kelompok I & $\begin{array}{l}\text { Kabid. } \\
\text { Layanan }\end{array}$ \\
\hline 24 & $\begin{array}{l}\text { Jumat, } 11 \\
\text { Maret } 2016\end{array}$ & $\begin{array}{l}\text { Direktorat } \\
\text { Sistem dan } \\
\text { Sumber Daya } \\
\text { Informasi } \\
\end{array}$ & $13.00-15.00$ & Kelompok II & $\begin{array}{l}\text { Kabid. } \\
\text { Database }\end{array}$ \\
\hline 25 & \begin{tabular}{|l} 
Senin, 14 Maret \\
2016
\end{tabular} & Perpustakaan & $09.00-11.00$ & Kelompok I & $\begin{array}{l}\text { Kabid. } \\
\text { Layanan }\end{array}$ \\
\hline 26 & \begin{tabular}{|l|} 
Senin, 14 Maret \\
2016
\end{tabular} & Museum & $09.00-11.00$ & Kelompok II & $\begin{array}{l}\text { Kabid. } \\
\text { Database }\end{array}$ \\
\hline 27 & \begin{tabular}{|l|} 
Senin, 14 Maret \\
2016
\end{tabular} & $\begin{array}{l}\text { Tata Usaha dan } \\
\text { Rumah Tangga }\end{array}$ & $13.00-15.00$ & Kelompok III & $\begin{array}{l}\text { Kabid. } \\
\text { Layanan }\end{array}$ \\
\hline 28 & $\begin{array}{l}\text { Selasa, } 15 \\
\text { Maret } 2016\end{array}$ & \begin{tabular}{|l} 
Hukum dan \\
Organisasi
\end{tabular} & $09.00-11.00$ & Kelompok III & $\begin{array}{l}\text { Kabid. } \\
\text { Database }\end{array}$ \\
\hline 29 & \begin{tabular}{|l} 
Selasa, 15 \\
Maret 2016 \\
\end{tabular} & \begin{tabular}{|l} 
Humas dan \\
Keprotokolan \\
\end{tabular} & $09.00-11.00$ & Kelompok II & $\begin{array}{l}\text { Kabid. } \\
\text { Layanan }\end{array}$ \\
\hline 30 & $\begin{array}{l}\text { Selasa, } 15 \\
\text { Maret } 2016\end{array}$ & $\begin{array}{l}\text { Kantor Audit } \\
\text { Internal }\end{array}$ & $13.00-15.00$ & Kelompok I & $\begin{array}{l}\text { Kabid. } \\
\text { Database }\end{array}$ \\
\hline
\end{tabular}




\begin{tabular}{|c|c|c|c|c|c|}
\hline 31 & \begin{tabular}{|l} 
Rabu, 16 Maret \\
2016
\end{tabular} & \begin{tabular}{|l} 
Kantor Urusan \\
Internasional \\
\end{tabular} & $09.00-11.00$ & Kelompok III & $\begin{array}{l}\text { Kabid. } \\
\text { Layanan }\end{array}$ \\
\hline 32 & $\begin{array}{l}\text { Rabu, 16 Maret } \\
2016\end{array}$ & $\begin{array}{l}\text { Kantor Jaminan } \\
\text { Mutu }\end{array}$ & $09.00-11.00$ & Kelompok I & $\begin{array}{l}\text { Kabid. } \\
\text { Database }\end{array}$ \\
\hline 33 & $\begin{array}{l}\text { Rabu, 16 Maret } \\
2016\end{array}$ & $\begin{array}{l}\text { Pusat Inovasi } \\
\text { dan Kajian } \\
\text { Akademik } \\
\end{array}$ & $13.00-15.00$ & Kelompok II & $\begin{array}{l}\text { Kabid. } \\
\text { Layanan }\end{array}$ \\
\hline 34 & $\begin{array}{l}\text { Kamis, } 17 \\
\text { Maret } 2016\end{array}$ & \begin{tabular}{|l} 
Pusat \\
Keamanan dan \\
Ketertiban \\
Kampus \\
\end{tabular} & $09.00-11.00$ & Kelompok I & $\begin{array}{l}\text { Kabid. } \\
\text { Database }\end{array}$ \\
\hline 35 & \begin{tabular}{|l|} 
Kamis, 17 \\
Maret 2016 \\
\end{tabular} & $\begin{array}{l}\text { Pusat Inovasi } \\
\text { Agroteknologi }\end{array}$ & $09.00-11.00$ & Kelompok II & $\begin{array}{l}\text { Kabid. } \\
\text { Layanan }\end{array}$ \\
\hline 36 & \begin{tabular}{|l|} 
Kamis, 17 \\
Maret 2016 \\
\end{tabular} & $\begin{array}{l}\text { Pusat Pelatihan } \\
\text { Bahasa }\end{array}$ & $13.00-15.00$ & Kelompok III & $\begin{array}{l}\text { Kabid. } \\
\text { Database }\end{array}$ \\
\hline 37 & \begin{tabular}{|l|l} 
Jumat, 18 \\
Maret 2016 \\
\end{tabular} & \begin{tabular}{|l} 
Badan \\
Penerbitan \\
\end{tabular} & $09.00-11.00$ & Kelompok III & $\begin{array}{l}\text { Kabid. } \\
\text { Layanan }\end{array}$ \\
\hline 38 & $\begin{array}{l}\text { Jumat, } 18 \\
\text { Maret } 2016\end{array}$ & $\begin{array}{l}\text { Gadjah Mada } \\
\text { Medical Center } \\
(\text { GMC })\end{array}$ & $09.00-11.00$ & Kelompok II & $\begin{array}{l}\text { Kabid. } \\
\text { Database }\end{array}$ \\
\hline 39 & $\begin{array}{l}\text { Jumat, } 18 \\
\text { Maret } 2016\end{array}$ & $\begin{array}{l}\text { Rumah Sakit } \\
\text { Akademik } \\
\text { (RSA) }\end{array}$ & $13.00-15.00$ & Kelompok I & $\begin{array}{l}\text { Kabid. } \\
\text { Layanan }\end{array}$ \\
\hline 40 & $\begin{array}{l}\text { Senin, } 21 \text { Maret } \\
2016\end{array}$ & $\begin{array}{l}\text { Pusat } \\
\text { Kebudayaan } \\
\text { Koesnadi } \\
\text { Hardjasoemantri } \\
\text { (PKKH) } \\
\end{array}$ & $09.00-11.00$ & Kelompok III & $\begin{array}{l}\text { Kabid. } \\
\text { Database }\end{array}$ \\
\hline 41 & $\begin{array}{l}\text { Senin, } 21 \text { Maret } \\
2016\end{array}$ & $\begin{array}{l}\text { University Club } \\
\text { (UC) }\end{array}$ & $09.00-11.00$ & Kelompok I & $\begin{array}{l}\text { Kabid. } \\
\text { Layanan }\end{array}$ \\
\hline 42 & $\begin{array}{l}\text { Senin, } 21 \text { Maret } \\
2016\end{array}$ & $\begin{array}{l}\text { Grha Sabha } \\
\text { Pramana (GSP) }\end{array}$ & $13.00-15.00$ & Kelompok II & $\begin{array}{l}\text { Kabid. } \\
\text { Database }\end{array}$ \\
\hline
\end{tabular}


S e t e la h d i lak k k a n pencermatan ternyata ada unit kerja yang belum masuk dalam target survei klasifikasi arsip. Untuk itu, dibuat susulan permohonan survei klasifikasi arsip ke beberapa unit kerja. Adapun unit kerja yang menjadi tambahan/ susulan untuk dilakukan survei klasifikasi arsip adalah seperti yang tercantum pada tabel 5 .

Tabel 5

Jadwal Susulan Survei Klasifikasi Arsip di Lingkungan UGM

\begin{tabular}{|c|c|l|l|l|}
\hline No & Hari/ Tanggal & \multicolumn{1}{|c|}{ Unit Kerja } & Kelompok & \multicolumn{1}{|c|}{ Pendamping } \\
\hline 1 & Senin, 21 Maret 2016 & Dewan Audit & Kelompok I & Kabid. Layanan \\
\hline 2 & Senin, 21 Maret 2016 & $\begin{array}{l}\text { PT. Gama Multi } \\
\text { Usaha Mandiri } \\
\text { (PT. GMUM) }\end{array}$ & $\begin{array}{l}\text { Kelompok } \\
\text { II }\end{array}$ & Kabid. Database \\
\hline 3 & Senin, 21 Maret 2016 & UGM Residence & $\begin{array}{l}\text { Kelompok } \\
\text { III }\end{array}$ & Kabid. Layanan \\
\hline 4 & Senin, 21 Maret 2016 & $\begin{array}{l}\text { Pusat Studi } \\
\text { Energi }\end{array}$ & Kelompok I & Kabid. Database \\
\hline 5 & Senin, 21 Maret 2016 & $\begin{array}{l}\text { Paboratorium } \\
\text { Pengujian dan } \\
\text { Terpadu (LPPT) }\end{array}$ & $\begin{array}{l}\text { Kelompok } \\
\text { II }\end{array}$ & Kabid. Layanan \\
\hline
\end{tabular}

Sumber: Diolah dari Korespodensi Arsip UGM, 2016. 
Kebanyakan pada saat survei arsip ini, Tim Survei diterima oleh pejabat yang membawahi bidang tata usaha dan kearsipan di unit kerja tersebut beserta arsiparis atau petugas/ pengelola arsip unit kerja. Dengan demikian masukan-masukan yang diberikan kepada Tim Survei benarbenar informatif dan berkualitas tentang arsip-arsip yang tercipta di unit kerja masing-masing sehingga dapat dipergunakan untuk perbaikan draf klasifikasi arsip.

\section{Kompilasi Data Hasil Survei}

Hasil dari survei lapangan yang telah dilakukan, diperoleh banyak data tambahan tentang itemitem arsip yang tercipta di unit kerja. Data-data hasil survei tersebut kemudian dianalisis oleh Tim Penyusun Klasifikasi Arsip dan setelah itu dimasukkan kedalam draf awal klasifikasi arsip untuk perbaikan draf sebelumnya. Dengan demikian, hasil yang diperoleh dari survei ini benar-benar diakomodir oleh Tim Penyusun Klasifikasi Arsip untuk merevisi draf awal klasifikasi arsip.

\section{Penyempurnaan Draf}

\section{a. Focus Group Discussion (FGD)}

FGD dilakukan dalam rangka mendapatkan masukan dari berbagai pihak terkait untuk penyempurnaan draf klasifikasi arsip. FGD ini dilaksanakan pada tanggal 5-6 September 2016. FGD diselenggarakan dengan mengundang seluruh Kepala Kantor Fakultas di lingkungan UGM, perwakilan pusat studi, perwakilan dari laboratorium, perwakilan dari unit kerja di Kantor Pusat UGM, dan para arsiparis/ pengelola arsip di lingkungan UGM. Tabel 6 menunjukkan para peserta FGD Penyempurnaan Draf Klasifikasi Arsip:

Tabel 6

Peserta FGD Penyempurnaan Draf Klasifikasi

\begin{tabular}{|l|l|l|}
\hline No. & \multicolumn{1}{|c|}{ Nama/ Pejabat } & \multicolumn{1}{|c|}{ Unit Kerja } \\
\hline 1. & Kepala Kantor Administrasi (KKA) & Fakultas Biologi \\
\hline 2. & Kepala Kantor Administrasi (KKA) & $\begin{array}{l}\text { Fakultas Ekonomika dan } \\
\text { Bisnis }\end{array}$ \\
\hline 3. & Kepala Kantor Administrasi (KKA) & Fakultas Farmasi \\
\hline 4. & Kepala Kantor Administrasi (KKA) & Fakultas Filsafat \\
\hline 5. & Kepala Kantor Administrasi (KKA) & Fakultas Geografi \\
\hline
\end{tabular}




\begin{tabular}{|c|c|c|}
\hline 6. & Kepala Kantor Administrasi (KKA) & Fakultas Hukum \\
\hline 7. & Kepala Kantor Administrasi (KKA) & Fakultas Ilmu Budaya \\
\hline 8. & Kepala Kantor Administrasi (KKA) & Fakultas ISIPOL \\
\hline 9. & Kepala Kantor Administrasi (KKA) & Fakultas Kedokteran \\
\hline 10 . & Kepala Kantor Administrasi (KKA) & Fakultas Kedokteran Gigi \\
\hline 11. & Kepala Kantor Administrasi (KKA) & Fakultas Kedokteran Hewan \\
\hline 12. & Kepala Kantor Administrasi (KKA) & Fakultas Kehutanan \\
\hline 13. & Kepala Kantor Administrasi (KKA) & Fakultas MIPA \\
\hline 14. & Kepala Kantor Administrasi (KKA) & Fakultas Pertanian \\
\hline 15 . & Kepala Kantor Administrasi (KKA) & Fakultas Peternakan \\
\hline 16. & Kepala Kantor Administrasi (KKA) & Fakultas Psikologi \\
\hline 17. & Kepala Kantor Administrasi (KKA) & Fakultas Teknik \\
\hline 18. & Kepala Kantor Administrasi (KKA) & Fakultas Teknologi Pertanian \\
\hline 19. & Kepala Kantor Administrasi (KKA) & Sekolah Vokasi \\
\hline 20. & Kepala Kantor Administrasi (KKA) & Sekolah Pascasarjana \\
\hline 21. & Sigit Sasongko, A.Md. & Fakultas Farmasi \\
\hline 22. & Noorsa Andjani, A.Md. & Fakultas Kedokteran \\
\hline 23. & Fidya Alfian Rahmawati, A.Md. & Fakultas Kedokteran Gigi \\
\hline 24. & Indriana Rinukti, A.Md. & Fakultas MIPA \\
\hline 25. & Sri Darwanti & Fakultas Pertanian \\
\hline
\end{tabular}




\begin{tabular}{|l|l|l|}
\hline 26. & Sri Lestari, S.IP. & Fakultas Peternakan \\
\hline 27. & Tri Muryani & Fakultas Psikologi \\
\hline 28. & Ari Marwanti, A.Md. & $\begin{array}{l}\text { Magister Administrasi Pul } \\
\text { (MAP) }\end{array}$ \\
\hline 29. & Silva Meliana, A.Md., S.Pd. & Pusat Studi Pancasila \\
\hline 30. & Fitria Yuniarti, S.H. & HUKOR \\
\hline 31. & Rustanti & TURT \\
\hline 32. & Mawaddah & $\begin{array}{l}\text { Laboratorium Penelitian d } \\
\text { Pengujian Terpadu (LPPT }\end{array}$ \\
\hline 33. & Pratiwi Muji Astuti, S.Psi & Pusat Inovasi Agro- \\
& & Teknologi (PIAT) \\
\hline 34. & Ully Isnaeni Effendi, A.Md., S.E. & Arsip UGM \\
\hline 35. & Herman Setyawan, A.M.d., S.Pd. & Arsip UGM \\
\hline 36. & Kurniatun, A.Md., S.I.P. & Arsip UGM \\
\hline 37. & Musliichah, A.Md., S.I.P. & Arsip UGM \\
\hline 38. & Fitria Agustina, A.Md., S.I.P. & Arsip UGM \\
\hline 39. & Heri Santosa, A.Md., S.ST.Ars. & Arsip UGM \\
\hline 40. & Anna Riasmiati, A.Md., S.E. & Arsip UGM \\
\hline 41. & Isti Maryatun, A.Md. & Arsip UGM UGM \\
\hline 42. & Eko Paris B.Y., S.Kom. & \\
\hline
\end{tabular}

Sumber: Arsip UGM, 2016

Berdasarkan diskusi yang dilakukan dalam FGD tersebut diperoleh banyak masukan yang sistematis dan terarah mengenai item-item arsip yang tercipta di unit kerja di lingkungan UGM, baik dari para kepala kantor maupun para arsiparis/ pengelola arsip. Dengan demikian draf awal yang sebelumnya telah direvisi oleh Tim Penyusun Klasifikasi Arsip dengan memasukkan data hasil survei lapangan pun berubah lagi. Draf terakhir pasca 
penyelenggaraan FGD pun

kemudian disebut Draf

Klasifikasi Arsip pasca FGD.

Draf ini kemudian dibahas

internal Arsip UGM oleh

pimpinan Arsip dan seluruh

arsiparis.

Setelah pembahasan internal, draf Klasifikasi Arsip ini disosialisasikan kepada arsiparis dan pengelola arsip di lingkungan UGM dalam pertemuan yang diadakan pada tanggal 29 November 2016 . Hal ini dimaksudkan agar para arsiparis dan pengelola arsip memahami isi dari draf Klasifikasi Arsip dan m e $\mathrm{ng}$ e tah u i prose s penyusunannya yang kemudian akan ditetapkan dalam bentuk Peraturan Rektor UGM. Tabel 7 menyajaikan data peserta sosialisasi draf Klasifikasi Arsip.

Tabel 7

Unit Kerja Peserta Sosialisasi Draf Klasifikasi Arsip

\begin{tabular}{|c|l|c|l|}
\hline No & \multicolumn{1}{|c|}{ Unit Kerja } & No & \multicolumn{1}{|c|}{ Unit Kerja } \\
\hline 1 & Fakultas Biologi & 22 & Badan Penerbit dan Publikasi \\
\hline 2 & Fakultas Ekonomika \& Bisnis & 23 & MAP \\
\hline 3 & Fakultas Farmasi & 24 & Sekolah Pascasarjana \\
\hline 4 & Fakultas Farmasi & 25 & Perpustakaan \\
\hline 5 & Fakultas Farmasi & 26 & Bagian TURT \\
\hline 6 & Fakultas Filsafat & 27 & PKKK \\
\hline 7 & Fakultas Geografi & 28 & HUKOR \\
\hline 8 & Fakultas Hukum & 29 & Direktorat Pendidikan dan Pengajara \\
\hline 9 & Fakultas Isipol & 30 & Direktorat Keuangan \\
\hline 10 & Fakultas Ilmu Budaya & 31 & Direktorat Aset \\
\hline 11 & Fakultas Kedokteran & No & Unit Kerja \\
\hline 12 & Fakultas Kedokteran & 32 & Direktorat Perencanaan \\
\hline 13 & Fakultas Kedokteran Gigi & 33 & Direktorat Pengabdian Masyarakat \\
\hline 14 & Fakultas Kedokteran Hewan & 34 & Direktorat Kemahasiswaan \\
\hline 15 & Fakultas Kehutanan & 35 & Direktorat SDM \\
\hline 16 & Fakultas MIPA & 36 & DBSMB SV UGM \\
\hline 17 & Fakulats Pertanian & 37 & Pusat Studi Pancasila \\
\hline 18 & Fakultas Peternakan & 38 & PIAT \\
\hline 19 & Fakultas Psikologi & 39 & LPPT \\
\hline 20 & Fakultas Teknik & 40 & RSA UGM \\
\hline 21 & Fakultas Tekn. Pertanian & 41 & Arsip UGM \\
\hline & & & \\
\hline
\end{tabular}

Sumber: Diolah dari Arsip UGM, 2016 
Pada saat Sosialisasi Draf Klasifikasi Arsip tersebut masih banyak masukan dari arsiparis dan pengelola arsip unit kerja. Hal ini tentu saja membuat Tim Penyusun Klasifikasi Arsip bekerja kembali untuk merevisi draf pasca FGD tersebut. Setelah draf Klasifikasi Arsip terakhir selesai diperbaiki kemudian dicermati oleh seluruh arsiparis Arsip UGM, draf terakhir tersebut (draf final) kemudian diproses ke Bagian Hukum dan Organisasi (Hukor) UGM melalui sistem aplikasi Electronic Legal Drafting (ELEGAN) dengan laman https: elegan.simaster.ugm.ac.id. Aplikasi ini merupakan suatu sistem informasi yang dikembangkan Hukor UGM bekerja sama Direktorat Sistem dan Sumber Daya Informasi (DSSDI) UGM untuk mempermudah dan mempercepat proses pengajuan suatu peraturan atau surat keputusan.

Melalui aplikasi ELEGAN ini, proses komunikasi antara Arsip UGM dengan Hukor UGM berjalan dengan lebih cepat dan baik dalam rangka penyempurnaan draf Klasifikasi Arsip untuk diproses menjadi Peraturan Rektor tentang Klasifikasi Arsip (tahun 20162017).

Namun, pada tahun 2017 UGM mendapat undangan dari Kemenristekdikti untuk menghadiri acara uji publik rancangan Permenristekdikti tentang Penyelenggaraan Kearsipan di Lingkungan Perguruan Tinggi. Pimpinan Arsip UGM mendapat tugas dari pimpinan UGM untuk menghadiri kegiatan tersebut. Dalam waktu yang hampir bersamaan Arsip UGM mendapat undangan dari Kemenristekdikti untuk berkontribusi dalam penyusunan Permenristekdikti tentang Klasifikasi Arsip, Jadwal Retensi Arsip dan Sistem Klasifikasi Keamanan dan Akses Arsip (fokus pembahasan penulis pada klasifikasi arsip). Hal ini mengakibatkan proses pembuatan Peraturan Rektor tentang Klasifikasi Arsip harus "dipending" atau dihentikan terlebih dahulu sampai dua peraturan dari Kemenristekdikti tersebut disahkan/ diundangkan karena dua peraturan tersebut akan digunakan sebagai dasar dalam memperbaiki draf klasifikasi yang sudah ada.

\section{b. Pembahasan Klasifikasi Arsip di Kemenristekdikti}

Sebelum peraturan tentang klasifikasi arsip disahkan, perlu ditetapkan aturan umumnya terlebih dahulu yaitu aturan tentang penyelenggaraan kearsipan. B e g i t u p u la d e $n$ g a $n$ Kemenristekdikti, untuk mengatur masalah kearsipan secara umum maka peraturan tentang 
penyelenggaraan kearsipan di perguruan tinggi disusun terlebih dahulu. UGM diundang oleh Kemenristekdikti dalam kegiatan U j i Publik R ancangan
Permenristekdikti tentang Penyelenggaraan Kearsipan di Lingkungan Kemenristekdikti. Keterlibatan UGM dapat dilihat pada table 8 .

Tabel 8

Peranserta UGM dalam Kegiatan Uji Publik dan Sosialisasi Permenristekdikti tentang Penyelenggaraan Kearsipan di Lingkungan Perguruan Tinggi Tahun 2017-2018

\begin{tabular}{|c|l|l|}
\hline No. & \multicolumn{1}{|c|}{ Tanggal } & \multicolumn{1}{c|}{ Acara/ Kegiatan } \\
\hline 1. & $26-27$ Okt 2017 & $\begin{array}{l}\text { Uji Publik Rancangan Permenristekdikti } \\
\text { tentang Penyelenggaraan Kearsipan di } \\
\text { Lingkungan Kemenristekdikti. }\end{array}$ \\
\hline 2. & $\begin{array}{l}26-27 \text { April } \\
2018\end{array}$ & $\begin{array}{l}\text { Sosialisasi Permenristekdikti No. 78 } \\
\text { Tahun 2017 tentang Penyelenggaraan } \\
\text { Kearsipan di Lingkungan } \\
\text { Kemenristekdikti. }\end{array}$ \\
\hline
\end{tabular}

Sumber: Agenda Surat Masuk Arsip UGM, 2017-2018

Dengan disahkannya Permenristekdikti Republik Indonesia Nomor 78 Tahun 2017 tentang Penyelengaraan Kearsipan di Lingkungan Kemenristekdikti (tertanggal 20 Desember 2017) maka peraturan rektor yang berkaitan dengan bidang kearsipan harus disesuaikan dengan peraturan ini. Termasuk Peraturan Rektor UGM tentang Tata Naskah Dinas juga harus direvisi. Peraturan Rektor UGM Nomor 13 Tahun 2018 tentang Tata Naskah Dinas di Lingkungan UGM disahkan tanggal 16 Agustus 2018 menggantikan
Peraturan Rektor Universitas $\mathrm{Gadjah} \mathrm{Mad}$ a $\mathrm{Nomor}$ 2/P/SK/HT/2015 tentang Tata Naskah Dinas di Lingkungan UGM. Dalam Peraturan Rektor UGM Nomor 13 Tahun 2018 sudah disebutkan tentang Klasifikasi Arsip.

$\mathrm{N}$ a m u n, s e b e $1 \mathrm{u} \mathrm{m}$ Permenristekdikti Nomor 78 Tahun 2017 disahkan, dalam waktu yang hampir bersamaan peraturan tentang klasifikasi arsip juga sedangkan disiapkan (dikerjakan) oleh Kemenristekdikti. Hal ini dapat diketahui dari undangan 
Kemeristekdikti untuk beberapa

PTN termasuk UGM untuk turut berkontribusi dalam rangka penyusunan Permenristekdikti tentang KA, JRA, SKKAA di Lingkungan Kemenristekdikti. D e ngan me mbawa da n menyampaikan draf yang sudah tersusun sebelumnya dalam kegiatan tersebut, dapat dikatakan bahwa UGM turut berkontribusi d a 1 a m pe n y s u n a n Permenristekdikti tersebut. Peranserta UGM dalam kegiatan tersebut dapat dilihat pada tabel 9.

Tabel 9

Peranserta UGM dalam Kegiatan Penyusunan Permenristekdikti tentang KA, JRA, SKKAA di Lingkungan Kemenristekdikti Tahun 2017-2018

\begin{tabular}{|c|c|c|}
\hline No. & Tanggal & Acara/Kegiatan \\
\hline 1. & 21 April 2017 & $\begin{array}{l}\text { Memberikan Testimoni Terkait Pola } \\
\text { Klasifikasi Arsip UGM. }\end{array}$ \\
\hline 2. & 21 April 2017 & $\begin{array}{l}\text { Penyusunan KA, JRA, dan Sistem } \\
\text { Klasifikasi Keamanan dan Akses Arsip di } \\
\text { Perguruan Tinggi dan Kopertis. }\end{array}$ \\
\hline 3. & 4-5 Sept 2017 & $\begin{array}{l}\text { Penyempurnaan KA, JRA, SKKAA di } \\
\text { lingkungan Kemenristekdikti. }\end{array}$ \\
\hline 4. & $\begin{array}{l}18-20 \\
\text { September } \\
2017\end{array}$ & $\begin{array}{l}\text { Kunjungan kerja dalam rangka finalisasi } \\
\text { penyusunan KA, JRA, SKKAA }\end{array}$ \\
\hline 5. & $\begin{array}{l}26-27 \\
\text { September } \\
2017 \\
\end{array}$ & Finalisasi KA, JRA, SKKAA \\
\hline 6. & 20-22 Des 2017 & $\begin{array}{l}\text { Sinkronisasi SKKA Arsip Dinamis dengan } \\
\text { daftar informasi publik di lingkungan PTN }\end{array}$ \\
\hline 7. & 2-3 Mei 2018 & $\begin{array}{l}\text { Penyesuaian draf tentang KA, JRA dan } \\
\text { SKKAA }\end{array}$ \\
\hline 8. & $\begin{array}{l}15-17 \text { Nov } \\
2018\end{array}$ & $\begin{array}{l}\text { Bimtek Permenristekdikti No.23 Tahun } \\
2018 \text { tentang KA, JRA \& SKKA }\end{array}$ \\
\hline
\end{tabular}

Sumber: Agenda Surat Masuk Arsip UGM, 2017-2018 
Setelah pembahasan

beberapa kali akhirnya Permenristekdikti yang ditunggu pun disahkan yaitu Permenristekdikti Nomor 23 Tahun 2018 tentang Klasifikasi Arsip, Jadwal Retensi Arsip, dan Sistem Klasifikasi Keamanan dan Akses Arsip Dinamis (KA，JRA dan SKKAA) di Lingkungan Kementerian Riset, Teknologi, dan Pendidikan Tinggi (Kemenristekdikti), tertanggal 23 Juli 2018.

\section{S i n k r o n i s a s i d e n g n} Permenristekdikti

D e nga n e 1 u a r n y a Permenristekdikti Nomor 23 Tahun 2018 tentang KA, JRA dan SKKAA di
Lingkungan Kemenristekdikti, maka draf yang sudah dibuat oleh Tim Penyusun Klasifikasi Arsip harus disesuaikan dengan kode-kode subjek di Permenristekdikti tersebut. Perubahan kode ini sangat jauh apabila dibandingkan dengan kodekode pada tabel 1. Namun, secara isi tidak jauh berbeda hanya terdapat penambahan-penambahan untuk sub subjek dan sub sub subjek pada main subjek tertentu serta perubahan letak item-item arsip. Tabel 10 menunjukkan kode klasifikasi fungsi substantif dan fasilitatif yang telah $\mathrm{d}$ i s e s u a i k a $\mathrm{n}$ e $\mathrm{n}$ g a $\mathrm{n}$ Permenristekdikti No. 23 Tahun 2018.

Tabel 10

Fungsi Substantif dan Fungsi Fasilitatif

\begin{tabular}{|l|l|l|}
\hline \multicolumn{3}{|l|}{ FUNGS SUBSTANTIF } \\
\hline No. & Kode & \\
\hline 1. & TM & Penerimaan Mahasiswa \\
\hline 2. & KR & Kurikulum \\
\hline 3. & TD & Tenaga Pendidik \\
\hline 4. & KM & Kemasiswaan \\
\hline 5. & PK & Perkuliahan \\
\hline 6. & DI & Data, Informasi dan Pengembangan Akademik \\
\hline 7. & TA & Penunjang Akademik \\
\hline 8. & PT & Penelitian \\
\hline 9. & PM & Pengabdian kepada Masyarakat \\
\hline 10. & PJ & Publikasi Jurnal/ Buku \\
\hline 11. & WA & Wisuda dan Alumni \\
\hline 12. & JM & Penjaminan Mutu \\
\hline 13. & TP & Tata Pamong (Organ Universitas) \\
\hline
\end{tabular}


Khazanah: Jurnal Pengembangan Kearsipan, 2019, Vol 12(2)

\begin{tabular}{|l|l|l|}
\hline \multicolumn{3}{|l|}{ FUNGS FASILITATIF } \\
\hline No. & Kode & \\
\hline 1. & PR & Perencanaan \\
\hline 2. & HK & Hukum \\
\hline 3. & OT & Organisasi dan Ketatalaksanaan \\
\hline 4. & KA & Kearsipan \\
\hline 5. & TR & Ketatausahaan dan Kerumahtanggan \\
\hline 6. & PL & Perlengkapan \\
\hline 7. & HM & Hubungan Masyarakat \\
\hline 8. & DL & Pendidikan dan Pelatihan \\
\hline 9. & TI & Teknologi Informasi dan Komunikasi \\
\hline 10. & PA & Pengawasan \\
\hline 11. & KP & Kepegawaian \\
\hline 12. & KU & Keuangan \\
\hline 13. & BU & Badan Usaha \\
\hline
\end{tabular}

Sumber: Permenristekdikti Nomor 23 Tahun 2018

tentang KA, JRA dan SKKAA di Lingkungan Kemenristekdikti

Proses sinkronisasi antara draf yang dibuat oleh Tim Penyusun Klasifikasi Arsip dengan Permenristekdikti Nomor 23 Tahun 2018 dilakukan dengan cara sebagai berikut:

a. Melakukan pencermatan terhadap nama subjek, kode subjek, subsubjek dan sub subsubjek;

b. Melakukan pencermatan perubahan dan perpindahan sub subsubjek yang satu ke subjek atau subsubjek yang lainnya;

c. Membahas apakah suatu sub subsubjek yang ada di Permenristekdikti Nomor 23 Tahun 2018 sesuai dengan di UGM atau tidak;

d. Melakukan penyesuaian (melakukan penggantian nama subjek, kode subjek, subsubjek dan sub subsubjek) dengan Klasifikasi Arsip sesuai dengan Permenristekdikti Nomor 23 Tahun 2018;

e. Menambahkan permasalahan sub subjek atau sub subsubjek yang belum ada di Permenristekdikti Nomor 23 Tahun 2018 namun ada di UGM; dan

f. Finalisasi draf dengan penyesuaian sesuai dengan ketentuan format peraturan rektor dan bahasa hukum.

Adapun proses sinkrosinasi draf Klasifikasi Arsip dapat dilihat pada table 11 . 
Tabel 11

Proses Sinkronisasi Draf Klasifikasi Arsip

\begin{tabular}{|l|l|l|l|}
\hline No. & \multicolumn{1}{|c|}{ Tanggal } & \multicolumn{1}{|c|}{ Kegiatan } & Keterangan \\
\hline 1. & 24 Januari 2019 & $\begin{array}{l}\text { Pembahasan oleh Tim } \\
\text { Penyusun Klasifikasi Arsip }\end{array}$ & Kode: TM, TD, TI \\
\hline 2. & 1 Februari 2019 & $\begin{array}{l}\text { Pembahasan oleh Tim } \\
\text { Penyusun Klasifikasi Arsip }\end{array}$ & Kode: KM, PK, D \\
\hline 3. & 6 Februari 2019 & $\begin{array}{l}\text { Pembahasan oleh Tim } \\
\text { Penyusun Klasifikasi Arsip }\end{array}$ & Kode:TA, PT, PM \\
\hline 4. & 11 Februari 2019 & $\begin{array}{l}\text { Pembahasan oleh Tim } \\
\text { Penyusun Klasifikasi Arsip }\end{array}$ & Kode:WA, JM, TP \\
\hline 5. & 12 Februari 2019 & $\begin{array}{l}\text { Pembahasan oleh Tim } \\
\text { Penyusun Klasifikasi Arsip }\end{array}$ & Kode:PR, HK \\
\hline 6. & 15 Februari 2019 & $\begin{array}{l}\text { Pembahasan oleh Tim } \\
\text { Penyusun Klasifikasi Arsip }\end{array}$ & Kode:OT, KA, TR \\
\hline 7. & 19 Februari 2019 & $\begin{array}{l}\text { Pembahasan oleh Tim } \\
\text { Penyusun Klasifikasi Arsip }\end{array}$ & Kode:PL, HM \\
\hline 8. & 25 Februari 2019 & $\begin{array}{l}\text { Pembahasan oleh Tim } \\
\text { Penyusun Klasifikasi Arsip }\end{array}$ & Kode: DL, TI \\
\hline 9. & 14 Maret 2019 & $\begin{array}{l}\text { Pembahasan oleh Tim } \\
\text { Penyusun Klasifikasi Arsip }\end{array}$ & Kode:PA, KP \\
\hline 10. & 20 Maret 2019 & $\begin{array}{l}\text { Pembahasan oleh Tim } \\
\text { Penyusun Klasifikasi Arsip }\end{array}$ & Kode:KU, BU \\
\hline 11. & 16 April 2019 & $\begin{array}{l}\text { Upload draf ke sistem } \\
\text { aplikasi ELEGAN }\end{array}$ & Draf Final \\
\hline
\end{tabular}

Sumber: Data Primer, 2019

\section{Proses Pengajuan sebagai Peraturan} Rektor

Setelah sempat di-pending (dihentikan sementara) karena menunggu keluarnya Permenristekdikti Nomor 78 Tahun 2017 tentang Penyelengaraan Kearsipan di Lingkungan Kemenristekdikti dan Permenristekdikti Nomor 23 Tahun
2018 tentang KA, JRA dan SKKAA di Lingkungan Kemenristekdikti; serta Peraturan Rektor UGM Nomor 13 Tahun 2018 tentang Tata Naskah Dinas di Lingkungan UGM, maka draf Klasifikasi Arsip yang telah disesuaikan dengan tiga peraturan tersebut kembali diproses sebagai peraturan rektor dengan diajukan ke 
Hukor UGM melalui aplikasi ELEGAN-Electronic Legal Drafting (https:elegan.simaster.ugm.ac.id). Melalui aplikasi ini usulan Peraturan Rektor tentang Klasifikasi Aarsip dilakukan secara online, sehingga bisa lebih cepat, efektif, dan efisien. Adapun proses perbaikan draf setelah dikirim melalui ELEGAN disajikan pada tabel 12.

Tabel 12

Proses Penetapan sebagai Peraturan Rektor tentang Klasifikasi Arsip

\begin{tabular}{|c|c|c|c|}
\hline No. & Tanggal & Kegiatan & Keterangan \\
\hline 1. & 16 April 2019 & $\begin{array}{l}\text { Upload draf ke sistem } \\
\text { aplikasi ELEGAN }\end{array}$ & Draf Final \\
\hline 2. & 14 Mei 2019 & $\begin{array}{l}\text { Membahas lampiran } \\
\text { peraturan rektor }\end{array}$ & $\begin{array}{l}\text { Setelah mendapat } \\
\text { permintaan dari Hukor } \\
\text { UGM }\end{array}$ \\
\hline 3. & 20 Juni 2019 & $\begin{array}{l}\text { Membahas naskah } \\
\text { urgensi (Naskah } \\
\text { Akademik) sebagai } \\
\text { syarat pengajuan draf } \\
\text { peraturan rektor }\end{array}$ & $\begin{array}{l}\text { Dibuat setelah } \\
\text { mendapatkan } \\
\text { permintaan dari Hukor } \\
\text { UGM karena ini } \\
\text { merupakan hal yang } \\
\text { baru }\end{array}$ \\
\hline 4. & 11 Juli 2019 & $\begin{array}{l}\text { Koordinasi dengan } \\
\text { staf Hukor UGM }\end{array}$ & $\begin{array}{l}\text { Membahas lampiran } \\
\text { Peraturan Rektor dan } \\
\text { penyelarasan draf agar } \\
\text { sesuai dengan bahasa } \\
\text { hukum. }\end{array}$ \\
\hline 5. & 23 Juli 2019 & $\begin{array}{l}\text { Finalisasi draf (sudah } \\
\text { dilengkapi dengan } \\
\text { naskah urgensi dan } \\
\text { petunjuk penggunaan } \\
\text { kode klasifikasi arsip) } \\
\text { dan editing terakhir }\end{array}$ & $\begin{array}{l}\text { Disampaikan ke } \\
\text { pimpinan Arsip untuk } \\
\text { mohon review dan ijin } \\
\text { diproses ke ELEGAN } \\
\text { kembali. }\end{array}$ \\
\hline 6. & 5 Agustus 2019 & $\begin{array}{l}\text { Upload draf final ke } \\
\text { ELEGAN }\end{array}$ & $\begin{array}{l}\text { Menunggu penetapan } \\
\text { dari Rektor }\end{array}$ \\
\hline 7. & 19 Agustus 2019 & $\begin{array}{l}\text { Peraturan Rektor } \\
\text { UGMtentang } \\
\text { KLasifikasi Arsip di } \\
\text { Lingkungan UGM }\end{array}$ & Ditetapkan \\
\hline
\end{tabular}

Sumber: Data Primer, 2019 
Setelah mengikuti semua prosedur dan saran perbaikan dari Hukor UGM dipenuhi, akhirnya pada tanggal 19 Agustus 2019 Peraturan Rektor UGM tentang Klasifikasi Arsip di Lingkungan UGM pun disahkan (Peraturan Rektor UGM Nomor 16 Tahun 2019 tentang Klasifikasi Arsip di Lingkungan UGM).

\section{PENUTUP}

Berdasarkan pembahasan tersebut dapat diketahui bahwa proses pembuatan draf klasifikasi arsip sampai dengan menjadi Peraturan Rektor UGM tentang Klasifikasi arsip di Lingkungan UGM membutuhkan proses yang panjang dan rumit. Pembuatan peraturan rektor ini membutuhkan waktu selama empat tahun yaitu sejak tahun 2015 sampai 2019. UGM melalui Arsip UGM turut berkontribusi dalam pembuatan Permenristekdikti Nomor 23 Tahun 2018 tentang KA, JRA dan SKKAA di Lingkungan Kemenristekdikti. Dengan ditetapkannya Peraturan Rektor UGM Nomor 16 Tahun 2019 tentang Klasifikasi Arsip di Lingkungan UGM ini diharapkan agar semua unit kerja di lingkungan UGM dapat menerapkan klasifikasi arsip sejak penciptaan arsip, pemberkasan dan penyimpanan arsip. Penerapan klasifikasi arsip dengan baik akan mempermudah pada saat penyimpanan arsip; mempermudah pada saat penemuan kembali arsip; dan mempermudah pada saat proses penyusutan arsip. Dengan penerapan klasifikasi arsip yang baik di lingkungan UGM diharapkan kearsipan di UGM dapat lebih baik dan semakin maju serta dapat turut menyukseskan Gerakan Nasional Sadar Tertib Arsip (GNSTA) demi generasi yang akan datang.

\section{Daftar Pustaka}

Andi Prastowo, 2016, Memahami Metode-metode Penelitian, Suatu Tinjauan Teoritis dan Praktis, Ar Ruzz Media, Yogyakarta.

Sauki Hadiwardoyo, 2002, Terminologi Kearsipan, Arsip Nasional Republik Indonesia, Jakarta.

V. Wiratna Sujarwadi, 2014, Metodologi Penelitian, Pustaka Baru Press, Yogyakarta.

Ratu Fauziah. 2018. Penerapan Skema Klasifikasi dalam Sistem Kearsipan Elektronik di K.A.P X, Y, Z dan Rekan. Skripsi. Program Studi Ilmu Perpustakaan Fakultas Adab dan Humaniora Universitas Islam Negeri Syarif Hidayatullah, Jakarta.

Undang-Undang Republik Indonesia Nomor 43 Tahun 2009 tentang Kearsipan.

Peraturan Menteri Riset, Teknologi, dan Pendidikan Tinggi Republik Indonesia Nomor 78 Tahun 2017 tentang Penyelengaraan Kearsipan di Lingkungan Kementerian Riset, Teknologi, dan Pendidikan Tinggi

Peraturan Menteri Riset, Teknologi dan Pendidikan Tinggi Nomor 23 Tahun 2018 tentang Klasifikasi Arsip, Jadwal Retensi Arsip, dan Sistem Klasifikasi Keamanan dan Akses Arsip Dinamis di 
Lingkungan Kementerian Riset, Teknologi, dan Pendidikan Tinggi

Keputusan Sekretaris Jenderal

Departemen Pendidikan Nasional Nomor 41268/A.A1/KP/2008 tentang Pola Klasifikasi Kearsipan di Lingkungan Departemen Pendidikan Nasional.

Peraturan Rektor Universitas Gadjah Mada Nomor 408/P/SK/HT/2009 tentang Jadwal Retensi Arsip dan Pedoman Penyusutan Arsip di Lingkungan Universitas Gadjah Mada.
Peraturan Rektor Universitas Gadjah Mada Nomor 13 Tahun 2018 tentang Tata Naskah Dinas di Lingkungan Universitas Gadjah Mada.

"Pengantar Kearsipan", http://docplayer.info/31728652Pengantar-kearsipan-drasumartini.html, diakses 1 Agustus 2019 pukul 12.15 WIB. 